\title{
MARK1 Gene
}

National Cancer Institute

\section{Source}

National Cancer Institute. MARK1 Gene. NCI Thesaurus. Code C150279.

This gene plays a role in both cell polarity and microtubule dynamics. 